\title{
The effects of 4-MEI on cell proliferation, DNA breaking and DNA fragmentation
}

\author{
NorizadehTazehkand $\mathrm{M}^{1}$,Moridikia $\mathrm{A}^{2}$,Hajipour $\mathrm{O}^{3}$, Valipour $\mathrm{E}^{4}$,Timocin $\mathrm{T}^{5}$, Topaktas $\mathrm{M}^{5}$, Yilmaz $\mathrm{MB}^{6}$ \\ Chemical Injuries Research Center, Baqiyatallah University of Medical Sciences, Tehran, Iran. \\ moridikia63@gmail.com
}

\begin{abstract}
4-Methylimidazole (4-MEI) is a color widely found in cola drinks, roasted foods, grilled meats, coffee and other foods. This study was aimed to investigate the 4-MEI effects on the cell proliferation, purified circular DNA and DNA from cells of rats treated with the 4-MEI.

In this study, mouse 3T3-L1 cell line was treated with 4-MEI at concentrations of 300, 450, 600 and $750 \mu \mathrm{g} / \mathrm{mL}$ for 24 hours and 48 hours periods, after that cytotoxic effect of the 4-MEI was studied by MTT test. Also, the effect of 4-MEI on purified circular DNA ( $\mathrm{pET} 22 \mathrm{~b}$ ) was investigated by treating of the DNA with 4-MEI concentrations of $300,450,600$ and $750 \mu \mathrm{g} / \mathrm{ml}$.

DNA was extracted from liver cells of rats that have been treated with 4-MEI doses of 25 and $50 \mathrm{mg} / \mathrm{kg}$ for 10 week and it was subjected to agarose gel electrophoreses analyses.4-MEl significantly inhibited cell proliferation of 3T3-L1 cell line at highest concentration for $24 \mathrm{~h}$ and at all concentration for $48 \mathrm{~h}$ treatment time. DNA fragmentation assay showed that 4-MEl at $50 \mathrm{mg} / \mathrm{kg}$ concentration clearly produced characteristic DNA smear and no DNA laddering (200bp) was observed when mouse was exposed to 4-MEI. The results obtained from plasmid DNA damaging assay showed that 4-MEI has noeffect on the DNA, because the electrophoretic pattern of DNA treated with 4-MEl showed three bands on agarose gel electrophoresis as it was for untreated control. 4-MEI showed cytotoxic effect on 3T3-L1 cells but no effect on plasmid DNA breaking. According to DNA fragmentation assay 4-MEI has necrosis effects on mouse liver cells (Tab. 1, Fig. 4, Ref. 27). Text in PDF www.elis.sk. KEY WORDS: 4-Methylimidazole, MTT, DNA fragmentation, plasmid DNA breaking.
\end{abstract}

\section{Introduction}

The 4-Methylimidazole (4-MEI) is found in natural dyes during the ammonia and ammonia-sulfite caramelization processing (Maillard reaction) of carbohydrates. Caramel colors of foods have been grouped in 4 classes by the Joint FAO/WHO (Food and Agriculture Organization of the United Nations/World Health Organization) Expert Committee on Food Additives (JECFA), and the European Union Scientific Committee for Food (1). 4-MEI (a heterocyclic organic chemical compound) is extensively used in human foods. Caramel color (which is the most-used food and beverage coloring), dark beers and common brands of cola drinks may contain

${ }^{1}$ Chemical Injuries Research Center, Baqiyatallah University of Medical Sciences, Tehran, Iran, ${ }^{2}$ Chemical Injuries Research Center, Baqiyatallah University of Medical Sciences, Tehran, Iran, ${ }^{3}$ Department of Biology, Institute of Basic and Applied Sciences, Pamukkale University, Denizli, Turkey, ${ }^{4}$ Molecular Biology and Genetic Department, Bulent Ecevit University, Zonguldak, Turkey, ${ }^{5}$ Department of Biology, Institute of Basic and Applied Sciences, Cukurova University, Adana, Turkey, and ${ }^{6} \mathrm{Faculty}$ of Medicine, Department of Medical Biology, Cukurova University, Adana, Turkey

Address for correspondence:A.Moridikia, Chemical Injuries Research Center, Baqiyatallah University of Medical Sciences, Tehran, Iran.

Acknowledgements: This investigation was supported by a grant from Cukurova University science research project (FDK-2014-2617). more than $100 \mu \mathrm{g}$ of this compound per 12-ounce serving. Also, this substance is found in roasted foods, grilled meats, and coffee $(2,3)$.

Some researchers have reported regarding the detrimental effect of the commonly used substances, for example NTP, found equivocal evidence of carcinogenic activity in female rats (F344/N) based on increased incidence of mononuclear cell leukemia and no evidence of carcinogenic activity in male rats. However, the manufacturing of certain artificial caramel colorings can lead to the formation of carcinogens $(4,5)$. On the other hand, Caramel showed mutagenic activity in Salmonella typhimurium TA 100 (6). In contrast to these researches, other experimental studies reported that 4-MEI provide chemopreventive effects against some cancers $(5,7)$. The decreased incidences of tumors in rats were mentioned in the NTP results, but they were not given much prominence, because NTP commonly focuses on cytotoxic identification rather than cancer prevention (4).

According to our knowledge there are not enough studies regarding genotoxic and cytotoxic effects of the 4-MEI, so by considering the extreme usage of the 4-MEI worldwide, this study was aimed to investigate of the effects of 4-MEI on the inhibition of cell proliferation, DNA breaking and DNA fragmentation.

The 3T3-L1 cell line was originally derived from Swiss mouse embryo tissue by Dr. Howard Green of Harvard Medical School. The 3T3-L1 is most commonly used in short- and long-term nanotoxicological in vitro studies on cytotoxicity, cancer, biocompati- 


\section{1-375}

bility, or mechanisms of cellular uptake of nanoparticles $(8,9)$. MTT assays are well known tests for evaluation of chemoradiation studies and radiosensitivity $(10,11,12)$. MTT assays are well known to study chemosensitivity or toxicity of drugs in cell lines $(13,14)$. The assay is less common to study survival of cancer cells after irradiation, in particular when the MTT assay is performed for studying proliferation of treated cells. The base of this method is the formation of dark-colored formazan dye by reduction of the tetrazolium salt MTT by metabolically active cells (15).

A hallmark feature of apoptosis was the observation that nuclear DNA extracted from apoptotic cells was often degraded in an inter-nucleosomal pattern (16). That is, DNA cleavage during apoptosis occurred at sites between nucleosomes, protein-containing structures that occur in chromatin at approximate 200-bp intervals. This DNA fragmentation was often analyzed using agarose gel electrophoresis to demonstrate a "ladder" pattern (17). On the other hand, genomic fragments of irregular sizes are generally induced during necrotic cells, and a DNA smear is obtained during agarose gel electrophoresis (18).

The characteristics of the major classes of food coloring are that in order to express their genotoxicity and carcinogenicity, they must be metabolized to reactive intermediates that are capable of interacting covalently with DNA (19). Damage to DNA is likely to be a major cause of cancer and other diseases.

\section{Materials and method}

\section{Materials}

In this study, 4-MEI (CAS Number: 822-36-6, Purity: 98\%, Molecular Weight: 82.11) was purchased from Sigma Aldrich and used as a test substance. The molecular structure of the substance as shown in Figure 1.

In this research $\mathrm{pET} 22 \mathrm{~b}$ plasmid was purchased from Novagen and MTT dye (3-(4, 5-dimethylthiazol-2-yl)-2,5- diphenyl tetrazolium bromide), Dimethylsulfoxide (DMSO), mouse embryo 3T3L1 cells were purchased from the Sigma and RPMI 1640 medium was purchased from Life technologies.

\section{Assessment of cytotoxicity}

The mouse embryo 3T3-L1 cells were obtained from Department of Medical Biology, Medicine Faculty of Cukurova University, Adana, Turkey. The culture medium included Dulbecco's RPMI 1640 medium. The cell culture condition was $37^{\circ} \mathrm{C}$ in humidified 5 $\% \mathrm{CO}_{2}$ incubator. The inhibition of cell proliferation was evaluated by MTT assay. The MTT assay was performed according to the method from Mosmann (20). 3T3-L1 pre adipocytes were plated into microtiter plates at a density of $1 \times 10^{4}$ cells/well. After $24 \mathrm{~h}$, culture medium was replaced by $90 \mu \mathrm{L}$ RPMI 1640 combined

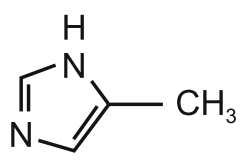

Fig. 1. The structure of 4-methylimidazole with $300,450,600,750 \mu \mathrm{g} / \mathrm{mL}$ of the 4-MEI (The tests for each concentration was repeated 8 times) and the cells were incubated for 24 and 48 hours (one group for $24 \mathrm{~h}$ and the other for $48 \mathrm{~h}$ ). The above mentioned concentrations were opted due to the LD50 $(750 \mu \mathrm{g} / \mathrm{ml})$ of the substance which was obtained by pre-tests in our lab. After the incubation time, $10 \mu \mathrm{l}$ sterile filtered MTT solution $(5 \mathrm{mg} / \mathrm{mL})$ in phosphate buffered saline (PBS, $\mathrm{pH}=7.4$ ) was added to each well and the cells were incubated for 5 hours, then unreacted dye was removed. The insoluble formazan crystals were dissolved in $200 \mu \mathrm{L} /$ well DMSO and measured spectrophotometrically in Medispec Esr-200 spectrophotometer at $570 \mathrm{~nm}$. The relative cell proliferation (\%) was calculated by equation of:

$$
\mathrm{A}_{570 \mathrm{~nm}}\left(\text { melanin) } / \mathrm{A}_{570 \mathrm{~nm}} \text { (untreated control) } \times 100\right.
$$

\section{Statistical analysis}

Data were presented as mean \pm S.D. Statistical analysis was performed using Student's t-test. In this research, statistical tests were performed using Minitab software.

Assessment of apoptosis and necrosis by DNA fragmentation assay

Male and female adult Swiss Albino Rats (4 male and 4 female) of body weight 80-90 g were obtained from the Medical Sciences, Experimental Research and Application Centre of Cukurova University, Turkey and were acclimatized to the control diet for 1 week. Animals were maintained as per the principles and guidelines of the Ethics Committee (FEF2014DK4). Animals were housed in separate cages as five animals per cage and were maintained in a controlled environmental condition of temperature $\left(22 \pm 2{ }^{\circ} \mathrm{C}\right)$ and humidity (45-70\%) on alternatively $12 \mathrm{~h}$ dark/light cycles. The animals were fed with commercial pellet diet and water.

After acclimatization periods (two weeks), the animals were grouped in four groups (each group comprised from five female and five male that were separately caged). 4-MEI were dissolved in double distilled water and administered as single dose in $1 \mathrm{ml}$ per rat intraperitoneal to each group as following:

- Group A, Control group (untreated control): The control groups only received normal diet (pellet and water).

- Group B: Received 25 mg/kg of 4-MEI (intraperitoneal injection) were administered five time a week for 10 weeks.

- Group C: Received $50 \mathrm{mg} / \mathrm{kg}$ of 4-MEI (intraperitoneal injection) were administered five time a week for 10 weeks.

After 4-MEI administration, animals were sacrificed by cervical dislocations and livers were harvested and stored at $-70^{\circ} \mathrm{C}$. For DNA extraction from liver tissues 1 gram of tissue was homogenized and cells suspended in $2 \mathrm{ml} \mathrm{NTE}$ (Mix $5 \mathrm{M} \mathrm{NaCl}, 100$ $\mathrm{mM}$ Tris- $\mathrm{HCl} \mathrm{pH}$ 7.5, $10 \mathrm{mM}$ EDTA pH 8 ) buffer and $2 \%$ trypsin (100 $\mu \mathrm{g} / \mathrm{ml}), 20 \%$ Sodium Dodecyl Sulfate (SDS) $(25 \mu \mathrm{l} / \mathrm{ml})$ and proteinase $\mathrm{K}(100 \mu \mathrm{g} / \mathrm{ml})$ and incubated at $37^{\circ} \mathrm{C}$ for overnight. After incubation, saturated phenol and chloroform were added. Then, they were centrifuged at 10,000 rpm for $10 \mathrm{~min}$ and finally the DNA was washed and precipitaded by Ethanol $70 \%$. The pellet (DNA) was dissolved in TE buffer $(21,22)$. After that, DNA 
(200ng from all samples) mixed with loading dye and electrophoresed on $1.8 \%$ agarose in Tris borate $(\mathrm{pH} 8)$ for $2 \mathrm{~h}$ at 150 volt. Gels were stained in $0.05 \mathrm{mg} / \mathrm{ml}$ ethidium bromide for 30 minute.

\section{Plasmid DNA Breaking Potential}

DNA damaging potential of 4-MEI was evaluated on $\mathrm{pET} 22 \mathrm{~b}$ plasmid DNA(Novagen). The experiments were performed in a volume of $10 \mu \mathrm{l}$ in a microfuge tube containing $3 \mu \mathrm{l}$ pET22b (150 ng) plasmid DNA, and $7 \mu \mathrm{l}$ of 4-MEI in the concentrations of 300, 450, 600 and $750 \mu \mathrm{g} / \mathrm{ml}$, respectively. In this research, untreated controls (untreated pET22b plasmid DNA) and positive controls ( $1 \mu \mathrm{lof}$ $30 \% \mathrm{H}_{2} \mathrm{O}_{2}, 3 \mu \mathrm{l}$ pET22b plasmid DNA, and $6 \mu$ of $\mathrm{H}_{2} \mathrm{O}$ ) were also used. The reactions were incubated at room temperature for $30 \mathrm{~min}$. After incubation, the reaction mixture $(5 \mu \mathrm{l})$ along with gel loading dye $(6 \times)$ was loaded on a $1.8 \%$ agarose gel for electrophoresis (23).

\section{Results}

The effects of 4-MEI on the inhibition of cell proliferation in 3T3L1 cell line

In order to do MTT assay, the cells were treated with different concentrations of the 4-MEI $(300,450,600$ and $750 \mu \mathrm{g} / \mathrm{ml})$ and incubated for 24 and 48 hours. After that cell concentration was assayed by spectrophotometer $\left(\mathrm{OD}_{570}\right)$ and subjected to calculation of relative cell concentrations. The cytotoxic effect of 4-MEI on 3T3-L1 cell line is shown in Table 1. In this study 4-MEI at highest concentration of $24 \mathrm{~h}$ and at all concentration for $48 \mathrm{~h}$ treatment time significantly inhibited cell proliferation when it was compared with control. The 4-MEI decreased the growth of the cells by about $13.41 \%$ at concentration of $750 \mu \mathrm{g} / \mathrm{ml}$ for 24 hours and 17.80 at concentration of $300 \mu \mathrm{g} / \mathrm{ml}, 20.07 \%$ at concentration of $450 \mu \mathrm{g} / \mathrm{ml}, 31.91 \%$ at concentration of $600 \mu \mathrm{g} / \mathrm{ml}$ and 39.77 $\%$ at concentration of $750 \mu \mathrm{g} / \mathrm{ml}$ for 48 hours treatment periods. Also, exposing to the 4-MEI for 48 hours leaded to a decrease in cells proliferation in concentration dependent manner (Fig. 2).

Assessment of apoptosis and necrosis by DNA fragmentation assay

DNA fragmentation in samples of mouse treated livers obtained from untreated and treated groups was studied by agarose gel electrophoresis (24). Genomic fragments of irregular sizes

Tab. 1. MTT assay of the 4-MEI in 3T3-L1 cell line.

\begin{tabular}{lccc}
\hline \multirow{2}{*}{ Test Substance } & \multicolumn{2}{c}{ Treatment } & \\
\cline { 2 - 3 } & $\begin{array}{c}\text { Time } \\
(\text { hours })\end{array}$ & $\begin{array}{c}\text { Concentration } \\
(\mu \mathrm{g} / \mathrm{ml})\end{array}$ & Mean value $(\%) \pm \mathrm{SE}$ \\
\hline Control & 24 & - & $0 \pm 1.76$ \\
\hline & & 300 & $-2.91 \pm 3.21$ \\
4-MEI & 24 & 450 & $-10.30 \pm 4.06$ \\
& & 600 & $0.46 \pm 1.69$ \\
Control & 48 & 750 & $13.41 \pm 0.541 \mathrm{a}_{3}$ \\
\hline & & - & $0 \pm 4.06$ \\
4-MEI & 48 & 300 & $17.80 \pm 4.04 \mathrm{a}_{2}$ \\
& & 450 & $20.07 \pm 4.52 \mathrm{a}_{2}$ \\
& & 600 & $31.91 \pm 3.63 \mathrm{a}_{3}$ \\
& & 750 & $39.77 \pm 1.02 \mathrm{a}_{3}$ \\
\hline
\end{tabular}

Data are expressed as the mean values $( \pm \mathrm{SE})$ obtained from 8 repeat; $(\mathrm{n}=8)$. A: significant from untreated control; $\mathrm{a}_{1} \mathrm{~b}_{1}: \mathrm{p}<0.05 ; \mathrm{a}_{2} \mathrm{~b}_{2}: \mathrm{p}<0.01 ; \mathrm{a}_{3} \mathrm{~b}_{3}: \mathrm{p}<0.001$.

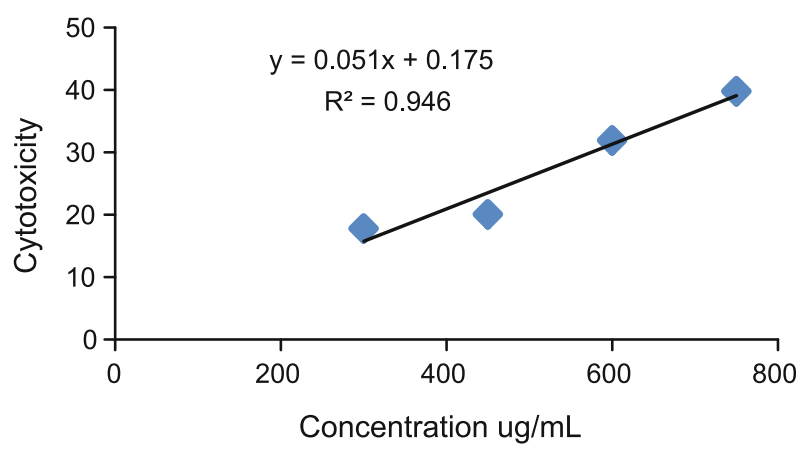

Fig. 2. The cell proliferation inhibition in 3T3-L1 cell line trearted with 4-MEI for $48 \mathrm{~h}$ treatment periods.

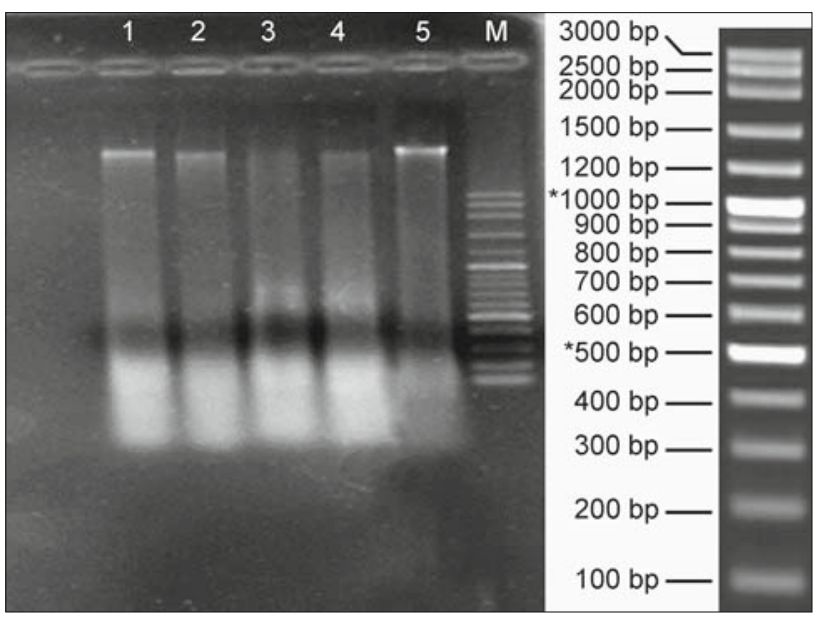

Fig. 3. The effect of 4-MEI on DNA fragmentation (lane $1,25 \mathrm{mg} / \mathrm{kg}$

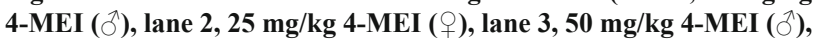
lane 4, $50 \mathrm{mg} / \mathrm{kg}$ 4-MEI grup ( + ), lane 5 , Untreated control, lane $M$, Marker.

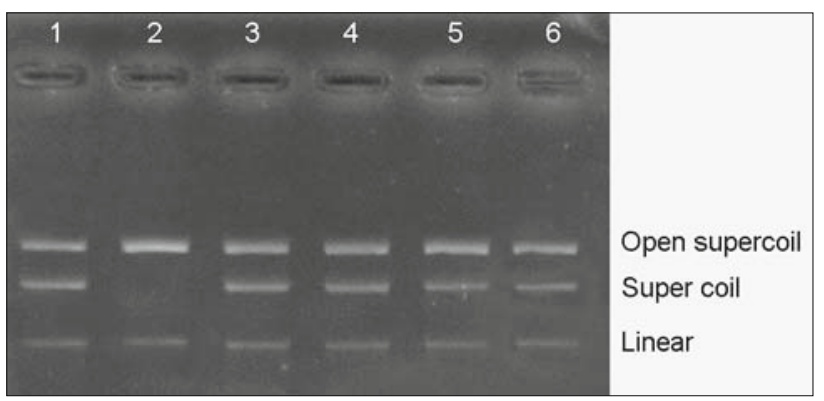

Fig. 4. Electrophoretic pattern of pET22b plasmid DNA after treatment with 4-MEI and $\mathrm{H}_{2} \mathrm{O}_{2}$. Lane 1: pET22b plasmid DNA (untreated control); lane 2: plasmid DNA treated with $\mathrm{H}_{2} \mathrm{O}_{2}$; lanes 3: pET22b plasmid treated with $300 \mu \mathrm{g} / \mathrm{ml}$ of 4-MEI; lanes 4: pET22b plasmid treated with $450 \mu \mathrm{g} / \mathrm{ml}$ of 4-MEI; lanes 5: pET22b plasmid treated with $600 \mu \mathrm{g} / \mathrm{ml}$ of 4-MEI; lanes 6: pET22b plasmid treated with 750 $\mu \mathrm{g} / \mathrm{ml}$ of 4-MEI.

are generally induced during necrotic cells, and a DNA smear is obtained during agarose gel electrophoresis (18). Figure 3 show the fragmentation of DNA from liver cells of mouse (which were treated with 25 and $50 \mathrm{mg} / \mathrm{kg}$ 4-MEIfor 10 week) and from control animals. The analysis showed that 4-MEI at $50 \mathrm{mg} / \mathrm{kg}$ concentra- 
371-375

tion clearly produced characteristic DNA smear and no DNA laddering (200 bp). Also, exposing to the 4-MEI leaded to an increase in DNA smear in a concentration dependent manner. According to this result 4-MEI has necrotic effects on mouse cells.

\section{DNA breaking}

Figure 4 shows the electrophoretic pattern of plasmid DNA after 4-MEI and $\mathrm{H}_{2} \mathrm{O}_{2}$ treatment. pET22b plasmid DNA showed three bands on agarose gel electrophoresis (untreated control) comprised of super coil, open supercoil and linear DNA. The pET22b plasmid treated with $\mathrm{H}_{2} \mathrm{O}_{2}$ (positive control) showed the cleavage of supercoiled circular DNA on the agarose gel indicating that the $\mathrm{OH} \cdot$ generated from $\mathrm{H}_{2} \mathrm{O}_{2}$ broken DNA strand. pET22b plasmid DNA treated with $\mathrm{H}_{2} \mathrm{O}_{2}$ showed two bands on agarose gel electrophoresis comprised from open supercoil and linear DNA. As it was shown in Figure 4, the electrophoretic pattern of DNA treated with 4-MEI ((concentrations of 300, 450, 600 and $750 \mu \mathrm{g} / \mathrm{ml}$ ) showed three bands on agarose gel electrophoresis as untreated control, comprised from super coil, open supercoil and linear DNA. Therefore 4-MEI did not break the plasmid DNA.

\section{Discussion}

According to our knowledge, this is the first study that addresses the cytotoxic potential of 4-MEI in 3T3-L1 cell line. In this research the MTT assay was carried out to measure cytotoxicity. The assay showed that 4-MEI at highest concentration of $24 \mathrm{~h}$ and at all concentration for $48 \mathrm{~h}$ treatment time significantly inhibited cell proliferation of 3T3-L1 cell line. The result of this study showed that 4-MEI has cytotoxic effect on cells. The results obtained from DNA fragmentation assay showed that 4-MEI at 50 $\mathrm{mg} / \mathrm{kg}$ concentration clearly produced characteristic DNA smear and no DNA ladders (200 bp) were observed. According to this result, 4-MEI has necrosis effects on mouse cells.

Short-term genotoxicity assays for the detection of potential human carcinogens have been used by many investigators and have been validated in international collaborative programs (25). Similarly, we tested the effect of 4-MEI on plasmid DNA breaking.

The results obtained from plasmid DNA damaging assay showed that 4-MEI has no effect on DNA breaking, because, the electrophoretic pattern of DNA after 4-MEI treatment showed three bands on agarose gel electrophoresis as untreated control comprised of super coil, open supercoil and linear DNA. According to the findings of this research, it can be said that 4-MEI have cytotoxic effect on 3T3-L1 cell line and have necrotic effect on rat liver cells. Rayes studied the effects of histological and microbiological effects of cola-flavored soft drink on bacterial strains. According to the result of Rayes research, Cola soft drinks were alarming since it was lethal to pathogenic bacteria tested strains (Bifidobacterium bifidum and Lactobacillus acidophilus) and had deleterious effects on the normal flora of the intestinal tract and toxic effect on the mice testicular cells (26). On the other hand, Caramel is the main substance in Cola soft drinks, and it showed mutagenic activity in Salmonella typhimurium TA 100 (6). There were no more reports regarding the genotoxicity or cytotoxicity of 4-MEI in the available literature. Matsui et al. reported that imidazole is an antifungal agent and the cytotoxic action of imidazole on fungal cells may be related to their action on membrane $\mathrm{Zn} 2+$ permeability (27). So it is possible that the cytotoxic effect of 4-MEI resulted from the same mechanism as imidazole effect on fungal cells.

\section{Conclusion}

As a result, 4-MEI has cytotoxic effect on 3T3-L1 cell line and has necrotic effect on rat liver cells. The result of plasmid DNA breaking assay showed that 4-MEI has no effect on plasmid DNA breaking. Therefore, it can be concluded that 4-MEI might pose a potential risk for humans. However, it must be evaluated with different new studies.

\section{References}

1. Müller LW, Langseth E. Solheim T. Isolation and characterization of alkyl-substituted imidazoles in ammoniated forage and in milk. J Agric Food Chem 1998; 46: 3172-3177.

2. Jacobson MF. Petition to Bar the Use of Caramel Colorings Produced With Ammonia and Containing the Carcinogens 2-Methylimidazole and 4-Methylimidazole. Center for Science in the Public Interest. Washington: Retrieved, 2011: 1-11.

3. Office of environmental health hazard assessment. 4-methylimidazole. 2011.

4. National Toxicology Program (NTP). NTP Technical Report on the Toxicology and Carcinogenesis Studies of 4-Methylimidazole (CAS No. 822-36-6) in F344/N Rats and B6C3F1 Mice. NTP TR-535. Research Triangle Park, NC. 2007.

5. Chan PC, Hill GD, Kissling GE, Nyska A. Toxicity and carcinogenicity studies of 4-methylimidazole in F344/N rats and B6C3F1 mice. Arch Toxicol 2008; 82: 45-53.

6. Jensen NJ, Willumsen D, Knudsen I. Mutagenic activity at different stages of an industrial ammonia caramel process detected in Salmonella typhimurium TA 100 following pre-incubation. Food Cosmet Toxicol 1983; 21: 527-530.

7. Murray FJ. Does 4-methylimidazole have tumor preventive activity in the rat? Food Chem Toxicol 2011; 49: 320-322.

8. Rosen ED, Spiegelman BM. Molecular regulation of adipogenesis. Ann Rev Cell Dev Biol 2000; 16: 145-171.

9. Napierska D, Thomassen LC, Lison D, Martens JA, Hoet PH. The nanosilica hazard: another variable entity. Part Fibre Toxicol 2010; 7 (1): $39-71$.

10. Pauwels B, Korst AE, Pooter CM, Pattyn GG, Lambrechts HA, Baay MF, Lardon F, Vermorken JB. Comparison of the sulforhodamine $\mathrm{B}$ assay and the clonogenic assay for in vitro chemoradiation studies. Cancer Chemother Pharmacol 2003; 51: 221-226.

11. Saunders MI: Predictive testing of radiosensitivity in non-small cell carcinoma of the lung. Lung Cancer 1994; 10 (1): 83-90.

12. Eble MJ, Hensley FW, Flentje M, Schlotz A, Wannenmacher M. A modified computer-assisted colorimetric microtitre assay (MTT) to assess in vitro radiosensitivity of V79, CaSki, HeLa and WiDr cells. Int J Radiat Biol 1994; 65: 193-201. 
13. Kratzke RA, Kramer BS. Evaluation of in vitro chemosensitivity using human lung cancer cell lines. J Cell Biochem Suppl 1996; 24:160-164.

14. Foldbjerg R, Dang DA, Autrup H. Cytotoxicity and genotoxicity of silver nanoparticles in the human lung cancer cell line, A549. Arch Toxicol 2011; 85 (7): 743-750.

15. Hansen J, Bross P. A cellular viability assay to monitor drug toxicity. Methods Mol Biol 2010; 648: 303-311.

16. Compton MM. A biochemical hallmark of apoptosis: internucleosomal degradation of the genome. Cancer Metastasis Rev 1992; 11: 105-119.

17. Jae A, Collins CA, Schandl KK, Young JV, Mark CW. Major DNA Fragmentation Is a Late Event in Apoptosis. JHC 1997; 45 (7): 923-934.

18. Schultze-Osthoff K, Walczak H, Droge W, Krammer PH. Cell nucleus and DNA fragmentation are not required for apoptosis. J Cell Biol 1994; 127: 15-20.

19. Weisberger JH. Antimutagens and anticarcinogens and effective worldwide cancer prevention. Toxicol Oncol 199; 18: 85-93.

20. Mosmann T. Rapid colorimetric assay for cellular growth and survival: application to proliferation and cytotoxicity assays. J Immunol Methods 1983; 65: 55-63.

21. Fehsel K, Kolb BV, Kolb H. Analysis of TNF alphainduced DNA strand breaks at the single cell level. Am J Pathol. 1999; 139: 251-254.
22. Negoescu A, Lorimier P, Labat-Moleur F, Drouet C, Robert C, Guillermet CC. In situ apoptotic cell labeling by the TUNEL method: improvement and evaluation on cell preparations. J Histochem Cytochem.1996; 44: 959-968.

23. Tepe B, Degerli S, Arslan S, Malatyali E, Sarikurkcu C. Determination of chemical profile, antioxidant, DNA damage protection and antiamoebic activities of Teucrium polium and Stachys iberica. Fitoterapia 2011; 82: 237-246.

24. Ikeda H, Suzuki Y, Suzuki M, Koike M, Tamura J, Tong J, Nomura M, Itoh G. Apoptosis is a major form of cell death caused by ischemia and ischemia reperfusion injury to the rat intestinal epithelium. Gut 1998; 42: 530-537.

25. ICPEMC. International Commission for Protection Against Environmental Mutagens and Carcinogens. Publication No. 16. Testing for mutagens and carcinogens; the role of short-term genotoxicity assays. Mutat Res 1988; 205: 3-12.

26. Rayes AAH. Effect of Some Drinks on the Benificial Probiotic Bacteria and the Structure of Testis of Male Albino Mice. J Appl Sci Res 2008; 4: 803-813.

27. Matsui H, Sakanashi Y, Oyama TM, Oyama Y, Yokota S, Ishida S, Okano Y, Oyama TB, Nishimura Y. Imidazole antifungals, but not triazole antifungals, increase membrane $\mathrm{Zn} 2+$ permeability in rat thymocytes possible contribution to their cytotoxicity. Toxicology 2008; 27: 142-150.

Received December 17, 2015. Accepted January 15, 2016. 